\title{
Pornography and Freedom
}

\section{Danny Frederick}

\begin{abstract}
I defend pornography as an important aspect of freedom of expression, which is essential for autonomy, self-development, the growth of knowledge and human flourishing. I rebut the allegations that pornography depraves and corrupts, degrades women, is harmful to children, exposes third parties to risk of offence or assault, and violates women's civil rights and liberties. I contend that suppressing pornography would have a range of unintended evil consequences, including loss of beneficial technology, creeping censorship, black markets, corruption and extensive social costs.
\end{abstract}

Key words: Pornography, freedom of expression, sexuality, human rights

\section{Introduction}

Whe Williams Committee ${ }^{1}$ defined pornography as sexually explicit representation which has the function or intention of sexually arousing its audience. Similar definitions have been put forward by other official committees or commissions on pornography in Canada and America. ${ }^{2}$ Pornography appears to have few friends in high places. Governments generally censor and restrict it. Most religions abominate it and others seem at least to frown upon it. Academics for the most part find it distasteful, if not offensive or even heinous. The "quality" news media (press and television) avoid promoting it, often speak openly against it, and almost as often call for its suppression. A myriad of influential pressure groups lobby for prohibition of at least some of it. Artists and writers are perhaps less disdainful but seem keen to make a distinction between erotica (acceptable) and pornography (unacceptable). And the word "pornographic" is very widely used as a metaphor for the excessive and disgusting, as when gory violence or someone's eating habits are labelled "pornographic." The opposition to pornography comes from both left and right, from avowed radicals as well as from fusty old traditionalists.

1 Report of the Committee on Obscenity and Film Censorship (London: Her Majesty's Stationery Office, 1979), 103.

2 For a synopsis, see D. Howitt and G. Cumberbatch, Pornography: Impacts and Influences (London: Home Office Research and Planning Unit, 1990), 1-5. The synopsis includes radicalfeminist stipulative definitions of "pornography" in terms of images that degrade or exploit women, etc. Such revisionary definitions raise the question whether there is any pornography, that is, whether any pornography in the ordinary sense is also pornography in the revised sense. I ignore such revisionary definitions here.

(C) 2011 Danny Frederick

http://www.kritike.org/journal/issue 10/frederick december2011.pdf ISSN 1908-7330 
In spite of this repudiation by respectability, pornography is a thriving multi-billion-pound worldwide industry with millions of consumers of both sexes from apparently all walks of life. It is conceivable that the denouncers and the consumers are two separate groups of people; but one cannot help suspecting that such very general deprecation of pornography is to some extent hypocritical. It seems that, at least for some people - and perhaps for very many - pornography is a dirty secret. In contrast, I will argue that a free society without pornography is unthinkable, that an interest in pornography is not something of which one should be ashamed, and that suppression of pornography is a veritable social evil.

In section 2, I defend pornography as an important aspect of freedom of expression, which is essential for autonomy, self-development, the growth of knowledge and human flourishing. I also consider the common allegations that pornography depraves and corrupts, degrades women, is harmful to children, exposes third parties to risk of offence or assault, and violates women's civil rights and liberties. I argue that even if these allegations were true, most of them would not warrant suppressing pornography. In section 3, I argue that the common allegations are almost all false and that pornography should be recognised as a good. In section 4, I argue that suppressing pornography has a range of unintended evil consequences. In section 5, I conclude.

\section{Freedom of Expression}

A free society is, amongst other things, a society that safeguards freedom of expression, which includes freedom of speech but also covers nonverbal expression, such as images, music, sculpture, performances, fashions, styles, and so on. Since written or spoken pornography is speech and all pornography is expression, a free society is one that safeguards the freedom to produce and consume pornography - at least, provided there is not a very good reason not to do so.

Freedom of expression is a prerequisite of personal development and human flourishing. Adult persons are self-conscious beings who, unless they suffer some form of impairment, are not only able but also entitled to manage their own lives, to pursue their own conception of the good life in their own way, to discover for themselves, often by experimentation, what they want to do or to be, and to seek the sorts of companions, careers and niches that they conjecture to be most propitious to their development and to the fulfilment of their aims. Thus, freedom of expression is essentially part of the freedom, due to all autonomous beings, to run their own lives in the way they see fit, subject to the constraint of not interfering with other people's freedom to do the same. ${ }^{3}$

Sex is, for most people, a very important part of life. Whether we like it or not, we are inherently sexual beings; and for many people sexual

${ }_{3}^{3}$ J. S. Mill, On Liberty (Harmondsworth: Penguin, 1983), 75-140. 
relationships, and their integral sexual activities, are central to life's meaning. ${ }^{4}$ For some men and women, consuming or producing pornography is a significant part of their sexual life and enhances their enjoyment of it. Further, the experience of participating in the production or consumption of pornography, and the ideas for experimentation communicated by this medium, can contribute to the development of a person's sexuality and personality. ${ }^{5}$ The self is a work in progress; ${ }^{6}$ and we each need the scope to discover for ourselves, by trials and mistakes, who we are and who we are capable of being. Freedom of expression is essential to this; and that includes freedom to create, disseminate and consume pornography.

Many people are critical of pornography. For at least some of them, articulating and communicating these criticisms will be an important part of who they are, or of their development or aims. Such criticism is also part of freedom of expression; and it can be very important not just for the people who voice it but also for the producers and consumers of pornography, who may be prompted to reflect on their activities and to reconsider or revise them. Criticism from others is very helpful to our experimentation as it can help us to identify our mistakes and learn from them. ${ }^{7}$ So it is important that freedom of expression includes freedom to debate, to criticise and even to castigate or lambast. The protection of freedom of expression does not mean protection from criticism; indeed, it cannot do, for that would involve denying freedom of expression to the critics.

It is nevertheless commonly maintained that under some circumstances considerations of public safety may legitimate restrictions on freedom of expression. We need not dispute this here. One kind of circumstance is a national emergency, such as war, when the flow of information may perhaps need to be controlled to prevent the enemy obtaining useful information. But other risks can be invoked to defend controls on freedom of expression in peacetime. The risks alleged against pornography seem to fall into five categories:

(i) it tends to deprave and corrupt those who produce or consume it; 8

(ii) it degrades women by portraying them as sexual slaves or as subservient or inferior to men;"

${ }^{4}$ Matt Ridley, The Red Queen (London: Penguin, 1994); Michael Foucault, The History of Sexuality, Vol. 1 (New York: Vintage, 1978).

5 Nina Hartley, "Confessions of a Feminist Porno Star," in L. Gruen and G. Panichas eds., Sex, Morality, and the Law (London: Routledge, 1997), 196-98; Kate Ellis, et al. eds., Caught Looking (New York: Caught Looking Inc., 1986).

6 Karl Jaspers, General Psychopathology, trans. by J Hoenig and M. W. Hamilton, (Manchester: Manchester University Press, 1963), 761.

7 Karl Popper, "The Myth of the Framework," in his The Myth of the Framework (London: Routledge, 1994), 33-64.

8 Obscene Publications Act (London: Her Majesty's Stationery Office, 1959).

9 Catharine MacKinnon, Feminism Unmodified (Cambridge, MA: Harvard University Press, 1987), part III. 
(iii) it is harmful to children if they consume it or are used (as participants) in its production; ${ }^{10}$

(iv) it exposes third parties to risk of offence or assault; ${ }^{11}$

(v) it violates women's civil rights and freedom of expression. ${ }^{12}$

In this section I will consider whether each allegation if true would warrant restricting or suppressing pornographic expression. I will consider in section 3 whether the allegations are true.

First, if it is true that pornography depraves and corrupts those who produce or consume it, then surely it is a matter for adults to decide for themselves whether they want to engage in pornographic production or consumption, on the basis of its costs, risks and benefits. Many activities have their downsides. Most sports involve a risk of injury, even of serious injury. Casual or promiscuous sex involves risks to health and possibly to character. Many voluntary or charitable activities, for example in developing countries, involve risks to health and life. In many occupations more or less serious injuries are routine, such as soldiering, coal-mining, fishing, law enforcement, fire fighting, even typing (repetitive strain injury). Some occupations involve risks of suffering trauma or developing callousness, such as policing, the armed services or even medical work. It is also thought that all positions of power political, bureaucratic or corporate - involve a risk of corruption. The people who engage in any of these activities judge (sometimes, no doubt, mistakenly) that despite the downsides their activities are worthwhile; and the rest of us respect their freedom to act in accordance with their judgements. How could producing or consuming pornography be any different?

I think there are two ways in which it might seem to be so. The first way involves linking sexual depravity and corruption with tendencies toward crime or anti-social behaviour. This is the claim of the fourth allegation, which will be considered shortly. The second way is to view sexual depravity and corruption as in itself intolerable to society. ${ }^{13}$ But, as the people who choose it plainly do not regard it as intolerable, this amounts to imposing some people's conception of the good on other people who do not share it. A recent UK government proposal to restrict freedom of expression said of violent pornography that it is "abhorrent to most people and has no place in our society." 14 The same could have been said, and something like it probably often was said, about images of mixed-race couples in the southern states of the USA under racial segregation. Such arrant intolerance is incompatible with the principles of a free society in which people can flourish.

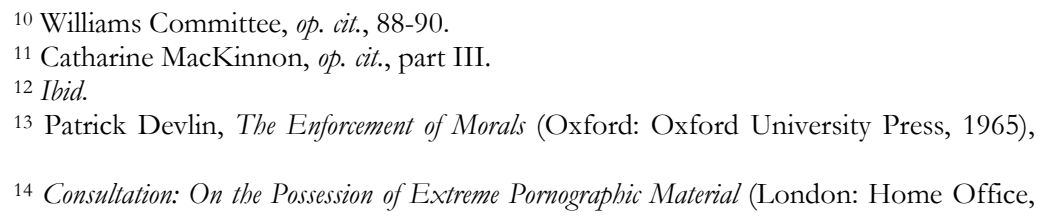


Second, the allegation that pornography degrades women seems to mean that the women are degraded if they engage in the production or consumption of pornography and that pornography communicates a negative opinion of women. If the first part of this allegation is true, then it is also true that the women, as consenting adults, should decide for themselves whether the degradation is worthwhile. (If any women participate against their will, then that is a matter of force or fraud, which should be dealt with separately from the issue of freedom of expression.) If the second part of the allegation is true, then the appropriate response is to criticise the opinion communicated by pornography. Indeed, the availability of pornography could be welcomed for the opportunity it provides to explain why the view it conveys is erroneous. Further, suppression of pornography would appear to be ineffective, since its characteristic opinion could still be expressed in non-pornographic media, such as academic books, television dramas, newspapers or political tracts. It might be contended that when the negative opinion of women is expressed pornographically it is dangerous; but this is part of the fourth allegation, to be considered below.

Third, if it is true that pornography is harmful to children, it is also true that alcohol, tobacco, medicines, sharp implements, and so on, are harmful to children. It is the responsibility of adults to see that children do not come into contact with these things or to see that children's use of them is properly supervised. In the case of pornography, for example, parents may prevent children from accessing pornography via the Internet by installing content-management software or making use of the filtering options made available to them by some Internet service providers. An incursion into adults' freedom of expression is not required.

Fourth, if it is true that pornography exposes third parties to risk of offence or assault, then even if this did justify controls over the production or consumption of pornography; it would do so only where less intrusive ways of dealing with the problems are not available. But the risk of offence to people who do not wish to view pornography can be avoided by regulations concerning what can be sold where, and by unobtrusive forms of sign-posting that identify where pornography is available, so that those who want it can find it, while others can avoid it. And if pornography somehow encourages its consumers to think that perpetrating sexual assaults is acceptable, an appropriate remedy would be better sex education, not only in schools and colleges, but throughout the media, and possibly also stiffer penalties for sexual offenders.

If pornography induces uncontrollable sex urges in its consumers, making them a danger to all, and to women in particular, this could be an argument for restricting freedom of expression, provided there are no alternative feasible options for countering the threat. Similarly, if the production or consumption of pornography inescapably involves violations of the civil rights or the freedom of expression of women, that could be an argument for prohibiting it, depending on the balance between the 
disadvantages of the violations and the disadvantages of prohibition. Whether pornography does have these effects is considered in the next section.

\section{Pornography Inherently Bad?}

In section 2, I assumed, for the sake of argument, that the allegations against pornography are true, and I argued that they would provide little, if any, ground for suppression of pornography. In this section I will argue that almost all of the allegations are false.

We can consider together the allegations that people who consume or produce pornography are made depraved and corrupt or, if they are women, degraded. First, it is puzzling why this should be true of material which is both sexually explicit and sexually arousing when it is not true of material which is either but not both. Some medical texts are sexually explicit. Some scenes in mainstream cinema are sexually arousing. If neither of these deprave, corrupt and degrade, why should something which combines the features of both do so? It is possible that it does; but it would need an explanation if true. Second, since the vast majority of people do have sex, often pretty regularly, and since such activity is an important and, for many people, a fulfilling part of life, it is again puzzling why it should deprave, corrupt or degrade when it is done in front of a camera or when it is viewed. The apparently obvious explanation of this is that sexual activities are properly private, while pornography makes them public and thereby de-sensitises those who participate in its production or consumption. ${ }^{15}$ But this just begs the question: in saying that sex is properly private, the case against pornography is assumed. No reason has been given for thinking that sex is properly private.

The allegation that pornography involves a violation of the civil rights and freedom of expression of women runs as follows. The negative view of women expressed by pornography conditions both men and women to see women as inferior and subordinate to men; and this shared presupposition fosters and entrenches sexual inequality, devalues women's speech and even creates a context in which women's demands for equal treatment are systematically misunderstood (for example, women's opinions may be dismissed when they contradict the picture of women presented by pornography). ${ }^{16}$ However, this would not amount to inequality of rights or a violation of women's freedom of expression. At most, it would identify prejudices that make it difficult for women to assert or utilise their rights, or to get their views taken seriously if they contradict the prejudices. The remedy for this would be a cultural change effected by changes in behaviour and opinion, and thus by making effective use of freedom of expression. Trying to effect that change by suppressing freedom of expression, on the other hand, could lead to far-reaching prohibition of opinions. For, any group that is or claims to

15 Williams Committee, op. cit., 96-98.

16 Catharine MacKinnon, op.cit., part III; Jennifer Hornsby and Rae Langton, "Free Speech and Illocution," Legal Theory, 4:1 (1998), 21-37. 
be disadvantaged could likewise demand suppression of views it deems unfavourable; and this could lead, for example, to proscription of performances of The Merchant of Venice, or films about professional women who neglect their children, or caricatures of homosexuals in nightclub routines. And creationists, flat-earthers and bigots, who have difficulty in getting their views taken seriously, would be entitled to demand the suppression of contrary opinions. ${ }^{17}$

However, the fundamental problem with the allegation about women's rights and freedom of expression is that it depends on the allegation that pornography communicates a negative opinion of women. This latter allegation is puzzling. Why should images or descriptions of women having sex communicate a negative opinion of women, given that the vast majority of women do have sex? And why should sexual representations of males and females having sex communicate a negative opinion of women if it does not communicate a negative opinion of men? Heterosexual pornography involves women and men, lesbian pornography involves only or largely women, while gay pornography involves only or largely men. Sadomasochistic pornography may involve men being subservient or inferior to women as well as vice versa. There is no asymmetry between the sexes which is inherent to pornography. ${ }^{18}$ Perhaps the complaint is that, while this medium is in principle neutral, it is in practice used to communicate a negative message about women. If this complaint were true, it would be an argument, not against pornography, but against the current style of pornography; and the remedy would be new pornography in a different style. But the complaint does not appear to be true in any case. For, there is enormous diversity in pornographic material; and its messages depend upon the viewer's interpretation. Further, the bulk of it appears, on the most obvious interpretation, to portray women as independent people who engage in sex because they enjoy it. ${ }^{19}$

It seems undeniable that some people are offended by pornography, but this can be avoided without suppression, as we noted above. However, the commonplace allegation that pornography leads to sexual offences is unsubstantiated, despite extensive empirical research into the effects of pornography on its consumers. The UK Home Office has commissioned two official reviews of this research, both of which have concluded that the evidence does not support a causal connection between the consumption of pornography and anti-social behaviour. ${ }^{20}$ This is not to deny the fact that some sexual offenders use pornography in the commission of their crimes. But it is also true that some of them use quotations from the Bible; that some use

${ }^{17}$ Ronald Dworkin, "Women and Pornography," in New York Review of Books, 40 (17), 36-42, 21 October 1993.

18 Gordon Hawkins and Franklin Zimring, Pornography in a Free Society (Cambridge: Cambridge University Press, 1988), 151-174.

${ }_{19}$ Nadine Strossen, Defending Pornography (New York: Doubleday, 1996), 141-178; Alan Soble, Pornography, Sex, and Feminism (Amherst, NY: Prometheus, 2002), 13-48.

${ }^{20}$ See references in notes 1 and 2. 
kitchen knives, or adhesive tape, or cigarettes, and so on. Anything may be so used.

I would guess that most of us are inclined to accept the allegation that consumption of pornography is harmful to children; but this might just reflect our upbringing or prevailing cultural norms. There is no rigorous scientific evidence that exposure to pornography causes harm to children since, for ethical reasons, experiments have not been conducted. Given that sex is an everyday and pleasurable activity that the vast majority of children will eventually engage in voluntarily, it is not clear why representations of such activity should affect them adversely, unless there happened to be something unusual or disturbing about the messages contained in the material or about the circumstances in which the children were introduced to it. But, as we saw above, even if the allegation is true, it does not mean that pornography is bad for adults, it just means that children and pornography should be kept separate. Similarly, if, as seems to me more likely to be the case, participating (un-coerced) in the production of pornography harms children, that is an argument for not permitting such participation, not an argument for restricting adults' use of, or participation in, pornography.

Having cleared away the allegations that pornography consumed by consenting adults is bad, we can now briefly note several ways in which it is good. First, as the size of the industry attests, many people simply enjoy it, either intrinsically, as something to contemplate, or as an aid to masturbation, or as a source of ideas for activities to undertake with a consenting adult sexual partner, or in some other way (who knows?). Second, some people may use it in general psychological, anthropological or other academic research. Third, some may use it in research for a novel or other fiction. Fourth, some people may use it as an aid to self-understanding. All, or almost all, of us have inclinations toward, or to be interested in, various forms of offbeat sexual activity. Some of us will have no wish to engage in such activity, perhaps because we do not accept that part of ourselves. But rather than repressing it, which may be unhealthy, we can explore or examine it in a detached way to achieve a reflective self-knowledge which helps us to pursue our lives and our self-development in ways that we value.

\section{Follies of Suppression}

Freedom of expression is to be prized as a condition of a free society and of individual autonomous development. However, suppression of freedom of expression is bad not only because it denies this good, but also because it inevitably has a range of unintended evil consequences.

First, specific exercises of freedom of expression often have spin-off benefits, and these indirect benefits can be valuable even to people who have no interest in the exercises of freedom of expression that led to them. For example, the high demand for pornography that can be consumed in private has driven technological developments in videotapes, DVDs, pay-per-view movie channels, interactive television, the internet, email and mobile 
telephones. The result has been speedy technical advance which improved the quality and reduced the cost of these services for all users, whether they have any interest in pornography or not. ${ }^{21} \mathrm{Had}$ pornography been suppressed, the technical innovations would have been delayed and some of them might never have been invented.

Second, the denial of freedom of expression requires the creation of the machinery of state censorship and suppression. Once this machinery exists, it is a prize that is eagerly sought by all intolerant groups and individuals who are keen to impose their conception of the good on everyone else. For example, in 1992, radical feminists in Canada succeeded in getting the obscenity laws amended to outlaw materials that are degrading or dehumanising to women. The change led to an epidemic of censorship affecting primarily gay, lesbian and feminist material. In the first two-and-a-half years, well over half of all Canadian feminist bookstores had material confiscated or detained by customs. ${ }^{22}$ In democratic societies, political policies inevitably involve concessions to, or "sweeteners" for, various organised groups and influential individuals whose support politicians are keen to obtain in their bids for re-election. ${ }^{23}$ As a consequence, once censorship is accepted as legitimate in one area, it tends to be extended to further areas, and there is little predicting which further incursions into freedom of expression will be made.

Third, prohibition of popular activities creates a bonanza for organised crime, as the US prohibition of alcohol in the early part of the twentieth century showed. Suppression of pornography would mean that a multi-billionpound industry is put into the hands of violent criminals who would use their enormous new wealth to finance criminal operations. It would raise the price and lower the quality of pornography for the consumer, it would make working life more hazardous for all those involved in producing pornography, and it would substantially increase the number of people, more especially women, who are forced into that type of work. Further, as with all black markets, it would create opportunities for wealthy criminals to bribe police officers, bureaucrats and politicians to turn a blind eye to the criminal activities or even to facilitate their operation, leading to extensive "depravity, corruption and degradation" in public life.

Fourth, suppressing pornography would involve a substantial reduction of social wealth. There would be a significant increase in the criminal justice costs of detection, apprehension, prosecution, and maintenance of the offenders in prison. There would be a substantial reduction in tax revenues because a huge, legal, tax-paying industry would be converted into a non-taxpaying activity, and because the people imprisoned would pay substantially less tax, not only because they are not working and spending while in prison, but also because they may find it difficult to obtain a legitimate job when released,

${ }^{21}$ John Arlidge, “The Dirty Secret that Drives New Technology: it's Porn," in The Observer, 3 March 2002.

22 Strossen, Defending Pornography, 229-32.

${ }_{23}$ Mancur Olsen, The Rise and Decline of Nations (New Haven: Yale University Press, 1982); Power and Prosperity (New York: Basic Books, 2000). 
having spent time in prison for a sexual offence. There would therefore also be an increase in welfare payments to support these people when they are released. All these costs would have to be borne by taxpayers; and they represent public money that could alternatively have been used to improve education, health, the environment or social services.

\section{Conclusion}

Freedom of expression, including the freedom to produce and consume pornography, as well as the freedom to criticise pornography, is essential to human flourishing and a free society. Suppression of freedom of expression seems defensible, if at all, only in special circumstances where it is the least pernicious means of avoiding substantial physical harm to third parties. Some of the allegations against pornography concern only risks to those who choose to produce or consume it; and, as consenting adults, those people are entitled to make their own decisions. Some of the allegations concern the message conveyed by pornography; but a free society, as well as the growth of knowledge, demands open discussion of any opinion. It is alleged that pornography is harmful to children; but this does not distinguish pornography from many other things which are not prohibited. Some allegations against pornography concern a risk to the safety of third parties; but such risks could be combated by means that avoid suppressing freedom of expression unless, perhaps, pornography turned people into compulsive offenders. It is also alleged that the existence of pornography violates women's rights and liberties.

However, few of the allegations commonly made against pornography seem true. It has not been explained how depictions of sex can deprave, corrupt or degrade, if sex itself does not deprave, corrupt or degrade. It has not been explained how pornography can essentially convey a negative opinion of women without essentially conveying a negative opinion of men, or why there is anything wrong with the explicit and arousing depiction of sexual activity. It would not be true that pornography involves a violation of women's rights or liberties even if it were true that pornography generally portrays women as subservient or inferior to men. But it is in any case false that pornography essentially, or even generally, conveys such a negative opinion of women. It is true that some people are offended by pornography; but they can avoid seeing it and regulatory arrangements could be improved to better enable this. However, the claim that pornography harms its adult producers, consumers or third parties is unsubstantiated. It is not known to what extent children are harmed by producing or consuming pornography; but, in any case, things can be arranged so that children have little chance of coming into contact with it, without restricting the freedom of adults to produce or consume it. Besides, pornography has many benefits as part of the sexual enjoyment and exploration of very many people, as material for research and as an aid to selfunderstanding and self-development. 
Suppression of pornography is therefore not only unnecessary but also inherently bad. In addition it has a range of unintended evil consequences. Like all suppressions of freedom, it will prohibit activities that can lead to discoveries which have utility in many other areas. The introduction of censorship invites and virtually ensures its extension. And suppression of pornography would lead to an extensive black market controlled by organised criminals with serious adverse consequences for all engaged in the production or consumption of pornography, as well as to widespread corruption in public life. It would also make substantial inroads into public funds which could be better spent improving the lives of the citizens.

Independent Researcher, United Kingdom

\section{References}

Arlidge, John, "The Dirty Secret that Drives New Technology: it's Porn," The Observer <http://www.guardian.co.uk/technology/2002/mar/03/ internetnews.observerfocus >, 3 March 2002.

Consultation: On the Possession of Extreme Pornographic Material (London: Home Office, 2005).

Devlin, Patrick, The Enforcement of Morals (Oxford: Oxford University Press 1965).

Dworkin, Ronald, "Women and Pornography," in New York Review of Books 40:17 (October 1993), 36-42, 21.

Ellis, Kate et al. eds., Caught Looking (New York: Caught Looking Inc., 1986).

Foucault, Michael, The History of Sexuality, Vol. 1. (New York: Vintage, 1978).

Hartley, Nina,. "Confessions of a Feminist Porno Star," in L. Gruen and G. Panichas eds., Sex, Morality, and the Law, 196-198 (London: Routledge, 1997).

Hawkins, Gordon and Zimring, Franklin, Pornography in a Free Society, (Cambridge: Cambridge University Press, 1988).

Hornsby, Jennifer and Langton, Rae, "Free Speech and Illocution," in Legal Theory, 4:1 (1998), 21-37.

Howitt D. and Cumberbatch, G., Pornography: Impacts and Influences (London: Home Office Research and Planning Unit, 1990).

Jaspers, Karl, General Psychopathology, trans. by J Hoenig and M. W. Hamilton (Manchester: Manchester University Press, 1963).

MacKinnon, Catharine, Feminism Unmodified (Cambridge, MA: Harvard University Press, 1987).

Mill, J. S., On Liberty (Harmondsworth: Penguin, 1983).

Obscene Publications Act (London: Her Majesty's Stationery Office, 1959).

Olsen, Mancur, The Rise and Decline of Nations (New Haven: Yale University Press, 1982).

, Power and Prosperity (New York: Basic Books, 2000).

Popper, Karl, "The Myth of the Framework," in The Myth of the Framework, 33 64 (London: Routledge, 1994). 
Ridley, Matt, The Red Queen (London: Penguin, 1994).

Report of the Committee on Obscenity and Film Censorship (London: Her Majesty's Stationery Office, 1979).

Soble, Alan, Pornography, Sex, and Feminism (Amherst, NY: Prometheus, 2002).

Strossen, Nadine, Defending Pornography, (New York: Doubleday, 1996). 